\title{
PROBLEM SOLVING ABILITY AND PROBLEM BASED LEARNING
}

\author{
Derry Nugraha ${ }^{1}$, Heri Ginanjar ${ }^{2}$, Rosalina Rolina ${ }^{3}$ \\ ${ }^{1,3}$ IKIP Siliwangi, Cimahi \\ ${ }^{2}$ STKIP PGRI, Sukabumi \\ ${ }^{1}$ n14d75@yahoo.com, ${ }^{2}$ nawwaaf_3@yahoo.com, ${ }^{3}$ maezarou@gmail.com
}

Received: Sep 11 ${ }^{\text {th }}, 2018$; Accepted: Sep $14^{\text {th }}, 2018$

\begin{abstract}
The research was caused by the poor of mathematical problem solving ability of students. This research aimed to compare of mathematical problem solving between students who learned through problem based learning and scientific approach. The method was an experimental method with a pretest-posttest control group design involving two groups and random sampling. At the first and end of learning, the two classes are given a test. The population in this research were Madrasah Aliyah students in Cimahi, while the sample consisted of two randomly selected classes. One class which was given problem based learning and other class was given a scientific approach. The instrument was a set of 5-item mathematical problem solving test description, then those were analyzed with descriptive and inferential statistics using the help of minitab 17 software. Based on the results of the research, the conclusion was the improvement of mathematical problem solving of students using problem based learning was better than students who use a scientific approach.
\end{abstract}

Keywords: problem solving, problem based learning, scientific approach.

\begin{abstract}
Abstrak
Penelitian ini dilatarbelakangi oleh masih rendahnya kemampuan pemecahan masalah matematik siswa. Penelitian ini bertujuan untuk membandingkan kemampuan pemecahan masalah matematik siswa antara yang pembelajarannya menggunakan problem based learning dan pendekatan saintifik. Metode yang digunakan dalam penelitian ini adalah metode eksperimen dengan disain kelompok kontrol pretes-postes yang melibatkan dua kelompok dan pengambilan sampel dilakukan secara acak kelas, pada awal dan akhir pembelajaran kedua kelas diberi tes. Populasi dalam penelitian ini adalah siswa Madrasah Aliyah di kota Cimahi, sedangkan sampelnya terdiri dari dua kelas yang dipilih secara acak. Satu kelas diberikan pembelajaran dengan problem based learning dan kelas lain diberi pendekatan saintifik. Instrumen yang digunakan adalah satu set bentuk tes uraian kemampuan pemecahan masalah matematik sebanyak 5 soal, kemudian data skor dianalisis dengan statistik deskriptif dan inferensial menggunakan bantuan software Minitab 17. Berdasarkan hasil penelitian, disimpulkan bahwa peningkatan kemampuan pemecahan masalah matematik siswa antara yang pembelajarannya menggunakan problem based learning lebih baik dari siswa yang menggunakan pendekatan saintifik.
\end{abstract}

Kata Kunci: pemecahan masalah, problem based learning, pendekatan saintifik.

How to Cite: Nugraha, D., Ginanjar, H., \& Rolina, R. (2018). Problem Solving Ability and Problem Based Learning. JIML, 1 (3), 239-243.

\section{INTRODUCTION}

One of the mathematical abilities that must be possessed by students is problem solving ability, namely the ability of students to solve non-routine math problems. So that students can get used to the problems faced. NCTM (2000) emphasizes the importance of problem solving because it is an integral part of mathematical understanding, so that it cannot be separated from mathematics learning. 
Sumarmo (2013) confirmed that problem solving is a general goal of learning mathematics, even as the heart of mathematics means problem solving ability is a basic ability in learning mathematics. This is also supported by the statement of Merdian, A., Sari, V. T. A. dan Sugandi, A. I. (2018) namely successful problem solving means success in mathematics as the content and strategy in solving problems. So that the problem solving ability is very important for students to understand mathematics. NCTM (2000) explained that mathematical problem solving abilities are essential abilities or competencies in learning mathematics, which are recommended to be trained and raised since children learn mathematics from elementary school onwards.

Problem based learning is learning that refers to the problem given. Sanjaya (2008) revealed that problem based learning begins with giving problems related to everyday life that must be completed by students. This learning requires students to explore and develop their own abilities in solving problems. Savery (2006) described that problem based learning is approach which can empowers students to research and solve problems.

Nilson (2010) said that problem based learning is a learning which allow students to solve the problems in many ways, it's open ended learning and students have in depth learning. But (Strobel, J., Barneveld, 2009) remaindered that problem based learning is a long term learning to be effective.

\section{METHOD}

This research method is an experimental study with pretest-posttest control group design, namely the design of pretest-posttest control groups involving two groups and randomly taking samples. The research design is described as follows Ruseffendi (2005):

$$
\begin{aligned}
& \text { AO XI O } \\
& \text { AO X2 O }
\end{aligned}
$$

Remarks:
A : Random sampling of class
$\mathrm{O} \quad$ : Problem pretest $=$ posttest question (problem of mathematical problem solving ability)
XI : Mathematics learning with PBL approach through TPSmodel
X2 : Mathematics learning with scientific approach

The population in this study were MA students in Cimahi City whose characteristics had low mathematical problem solving abilities. From all MAs in Cimahi City randomly selected, MAN Cimahi was chosen representing the characteristics of the population and has applied the scientific approach, to be used as a place of research. From this school, two classes were taken from class $\mathrm{X}$ randomly according to class to be used as samples, and selected class X IIS 1 became experimental class I, and class X IIS 3 became experimental class II. The selection of class X is due to the class that is in accordance with the material of the row and series to be studied. Descriptive statistics results score troubleshooting capabilities mathematically as follows:

\begin{tabular}{|c|c|c|c|c|}
\hline \multirow[t]{2}{*}{ Statistics } & \multicolumn{2}{|c|}{ Class Experiment I } & \multicolumn{2}{|c|}{ Class Experiment II } \\
\hline & pretest & posttest & Pretest & Posttest \\
\hline SMI & \multicolumn{4}{|c|}{20} \\
\hline $\mathrm{N}$ & \multicolumn{2}{|c|}{26} & \multicolumn{2}{|c|}{26} \\
\hline Score Lowest & 2 & 3 & 3 & 2 \\
\hline Top Score & 9 & 18 & 8 & 14 \\
\hline $\bar{x}$ & 5.00 & 9.15 & 4.73 & 6.70 \\
\hline $\mathrm{S}$ & 1.98 & 4.24 & 1.56 & 3.25 \\
\hline
\end{tabular}

Table 1. Descriptive Statistics Result Score Ability Problem Solving Mathematical 
Based on Table 1, the initial ability of mathematical problem solving between the two groups can be seen from the pretest scores performed before the agreed treatment is given. The mean pretest of the experimental class I was 5.00 while the mean of the experimental class II was 4.73 , the difference in the mean of the two groups was 0.27 indicating the score of the students' initial ability in each class was not much different. The final ability of mathematical problem solving can be seen from the posttest score. The mean posttest of experiment class I was 9.15, the mean of experiment II was 6.70 and the mean difference in posttest between the two groups was 2.45 , indicating that the final ability score of students in each class was much different after the treatment.

Table 2. Output Minitab17

\begin{tabular}{llll}
\hline \multirow{2}{*}{ Test } & of Value & \\
\cline { 3 - 4 } & & Class Experiment I & Class Experiment II \\
\hline \multirow{2}{*}{ Pretest } & Normality & 0.024 & 0,037 \\
\cline { 2 - 4 } & Mann Whitney & 0,7505 & \\
\hline \multirow{2}{*}{ Postes } & Normality & 0.150 & 0.010 \\
\cline { 2 - 4 } & Mann Whitney & 0.033 & \\
\cline { 2 - 4 }
\end{tabular}

\section{Discussion}

From Table 1 and the results of pretest data processing can be seen the average value of experimental class I and the experimental class II average, from the average it can be seen that the initial ability of the two groups is not different or the same, it is supported by the results of thetest data Mann Whitney which shows that there is no difference in the initial ability of students' mathematical problem solving between experimental classes I with experimental class II. In addition, the results can show that the two groups' mathematical problem solving abilities have not been satisfactory. One of the things that causes a lack of mathematical problem solving ability is that students are not accustomed to working on problem solving problems, so that at the time of students 'pretest they are confused to identify the known elements and the elements asked, thus implicating the students' inability to work on the problem solving problem. correctly.

This research was conducted ten meetings in both classes, two meetings were used for pretest and posttest and eight meetings were used for learning with different treatments, experiment class I got mathematics learning with PBL approach through TPS model, while experimental class II with scientific approach.

After the pretest was conducted, in the next meeting the two classes got learning with the same material, that is Barisan and Deret, but with different treatments as mentioned in the description above. In both classes this activity begins with a question and answer to stimulate students in remembering the material of the number pattern that has been learned in SMP / MTs, as an introductory material to study the material of the Sequence and Series. Both classes were given Student Activity Sheet (LAS) in the form of daily problems and problems that were not immediately found by the results and contained completion steps according to the approach given, for the experimental class I LAS in accordance with the characteristics of the PBL approach, for the experimental class II in accordance with characteristic of the scientific approach.

In the experimental class I, all learning steps are in accordance with the steps of the TPS type cooperative learning model. Before the TPS step begins students are first presented with problems in everyday life related to the material, because it is in accordance with the 
characteristics of the PBL approach that is exposing students to problems at the beginning of learning, and students are expected to be able to foster problem solving abilities. Then students think individually to identify the problem given (stage Think), form groups in pairs to discuss the results of the thoughts in the previous stage and complete the LAS (stage Pair) and the teacher becomes a facilitator to stimulate students to actively discuss, followed by sharing the results of the discussion with all groups in the class, so that a quarter of the many groups in the class have presented the results of the discussion (stage Share). After the discussion is complete, the teacher guides students to draw conclusions from the results of the discussion at the meeting.

Where as in experiment class II, the learning steps are in accordance with the steps of the scientific approach, namely observing, asking questions, gathering information, associating and communicating the results of the discussion. At the beginning of the learning the students were formed into several groups of five students, each group was given LAS to be discussed with the group. Each group is given the task of observing and digging up information related to material from several sources, when discussing the teacher gives freedom so that students are able to collect information and solve problems listed in LAS, which aims to form the ability to solve problems systematically in students. Furthermore, students are given a stimulus to be active in asking questions and discussing. After LAS finished working, students who were representatives of each group presented the results of the discussion, and continued with the conclusions drawn from the discussion with the teacher's direction.

Constraints faced in this study, for the experimental class I, namely in learning students are not used to using the PBL approach through the TPS model, so students are still confused when learning begins with problems and the form of paired groups, students have not been able to identify problems quickly and precisely so that it takes time long for this stage, but the researchers tried to optimize the available time so that the next stages were conveyed, besides that there were also students who were less active and ashamed to ask in learning activities.

In learning in experimental class II, the obstacles faced were not much different from the experimental class I. From the five steps to the scientific approach, the questioning step was a difficult step to be used by students. In addition there are students who still have difficulty in collecting information, associating, and communicating. But this obstacle can be overcome because at the school has implemented the 2013 curriculum, students are not too difficult to adjust learning with the scientific approach.

After the pretest and treatment, both classes are given a final test or post with the same questions on the pretest. From the results of the posttest obtained the average experimental class I and experimental class II, from the average of the two classes it can be seen that there are differences in students' mathematical problem solving abilities between the two classes. In addition, there was an increase in the average score in both classes, the experimental class I increased by 4.15 from the average pretest and experimental score II increased by 1.97 from the average pretest score. The following presented an average increase in the scores of both classes:

This was supported by the results of the posttest score data using MinitabSoftware 17withtest Mann Whitney which showed that there were differences in students' mathematical problem solving skills between the experimental class I whose learning uses the PBL approach through the TPS model with the experimental class II whose learning uses a scientific approach. So that the hypothesis has been answered, the acceptance of this hypothesis is supported by several factors including:

1. Research in accordance with procedures, and the ability of students who support.

2. PBL pincer characteristics correspond to indicators of problem solving ability. 


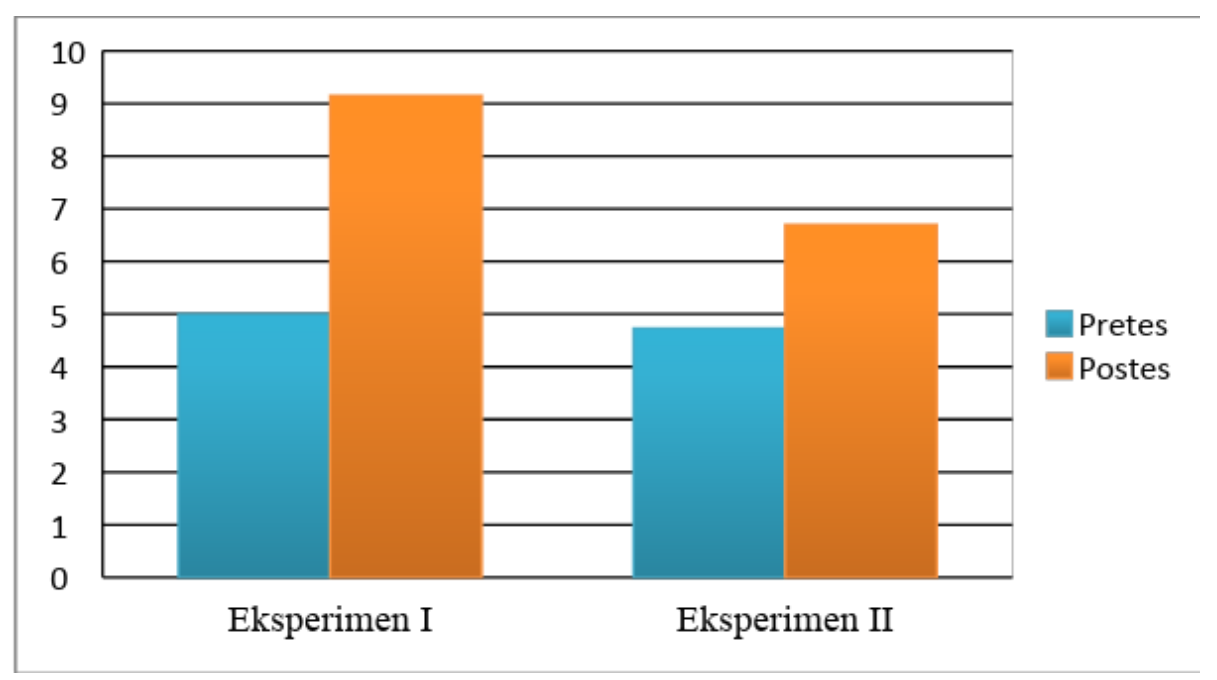

Figure 1 Average Score of Mathematical Problem Solving Ability

\section{CONCLUSION}

Based on the research that has been done about mathematical problem solving ability using problem based learning approach with scientific approach can be concluded that:

1. Achievement of mathematical problem solving ability students using problem based learning approach through is better than scientific approach.

2. There is no difference in improving mathematical problem solving ability of students using problem based learning approach and scientific approach.

\section{REFERENCES}

Merdian, A., Sari, V. T. A. dan Sugandi, A. I. (IKIP S. P. M. (2018). Analisis Kemampuan Komunikasi Matematis dan Keaktifan Siswa SMA dengan Pendekatan Problem Posing. SOSIOHUMANIORA: Jurnal LP3M - UST Yogyakarta, 4(1), 45-50. https://doi.org/10.30738/sosio.v4i1.2279

NCTM. (2000). Principles and Standards for School Mathematics. USA: NCTM.

Nilson, L. B. (2010). Teaching at its Best: A Research-Based Resource for College Instructors. San Fransisco: CA: Jossey-Bass.

Ruseffendi, H. E. T. (2005). Dasar-Dasar Penelitian Pendidikan dan Bidang Non- Eksakta Lainnya. Bandung: Tarsito.

Sanjaya, W. (2008). Strategi Pembelajaran Berorientasi Standar Proses Pendidikan. Yogyakarta: Graha Ilmu.

Savery, J. (2006). Overview of Problem-based Learning: Definitions and Distinction. Interdiscipkinary Journal of Problem-Based Learning, 1(1).

Strobel, J., Barneveld, A. (2009). When is PBL More Effective? A Meta-synthesis of Metaanalyses Comparing PBL to Conventional Classrooms. Interdiscipkinary Journal of Problem-Based Learning, 3(1).

Sumarmo, U. (2013). Kumpulan Makalah Berpikir dan Disposisi Matematik serta Pembelajarannya. Jurnal Pendidikan Matematika. 